УДК 629.891. (043.3)

DOI: $10.18372 / 0370-2197.3(88) .14918$

Д. О. ВОЛЬЧЕНКО ${ }^{1}$, М. В. КІНДРАЧУК ${ }^{2}$, В. С. СКРИПНИК ${ }^{1}$, М. О. ВОЛЬЧЕНКО, О. М. ВУДВУДН,

${ }^{1}$ Івано-Франківський національний технічний університет нафти і газу, Украйна

${ }^{2}$ Національний авіаційний університет, Украйна

${ }^{3}$ Кубанський держсавний технологічний університет, Росія

${ }^{4}$ Одеський національний політехнічний університет, Украйна

\title{
ТЕРМОСТАБІЛІЗАЦІЙНИЙ СТАН МЕТАЛЕВИХ ФРИКЦІЙНИХ ЕЛЕМЕНТІВ ГАЛЬМІВНИХ ПРИСТРОЇВ (ЧАСТИНА II)
}

В матеріалах статті розглянуто термостабілізаиійний стан ободу барабана, який підтримується міжконтактним іонізованим газовим середовищем і продуктами десорбиії вологи (з приповерхневого шару накладки) між подвійними електричними шарами («полірована робоча поверхня ободу барабана - робоча поверхня накладок» $i$ «робоча поверхня накладок (невзаємодіюча з робочою поверхнею ободу барабана автотранспортного засобу) - нижній рівень приповерхневого шару накладок). Виникаючі струми насичення сприяють інверсї̈ теплових потоків від полірованої робочої поверхні ободу барабана автотранспортного засобу в приповерхневі шари накладок, сприяючи його термостабілізаиійний стан. У сильно розведених розчинах електроліту границя дифузійного шару може змішуватися за гранищю так званого шару ковзання, тобто плошини, за гранииями якої стає можливим рух рідини уздовж міжфазової границі. Отже, при протіканні рідини уздовж границі «тверде тіло / рідина» відбувається перемішення об 'ємного заряду $i$, відповідно, з'являється різниця потенціалів вздовж потоку рідини. Явище, яке пов'язано з появою об'ємного заряду в розчині електроліту за межами площини ковзання називається електрокінетичним. Потенціал площини ковзання називають електрокінетичним потениіалом. Подвійні електричні шари у парах тертя відіграють важливу роль у підсиленні трибоефекту в парах тертя гальмівних пристроїв. Існування подвійного електричного шару на міжфазній границі двох середовищ (робоча поверхня гальмівного барабана - робоча поверхня полімерного фрикиійного елемента), а також на гарячій $і$ холодній поверхнях приповерхневого шару фрикиійної накладки відіграє важливу роль не тільки в іонному обміні між поверхнями тертя, але й у процесах адсорбиії іонів поверхонь пар тертя гальм. Наявність подвійного електричного шару істотно впливає на електроповерхневі процеси: провідності, поляризації дисперсних частинок, масо- $і$ енергопереміщення крізь заряджені дисперсні системи, електростатичної взаємодії між зарядженими частинками і таке ін. При иьому електроповерхневі прочеси є складовими електрокінетичних явищ, щяо мають місие у приповерхневих шарах фрикиійних накладок. Важливо відзначити, що основні дані про будову подвійного електричного шару отримано з ємнісних вимірювань за відсутності переносу зарядів крізь міжфазну граниџю. У реальних умовах роботи пристроїв молекулярної електроніки процес ускладнюється: стає можливим перенесення зарядів за рахунок електрохімічної реакції, іонізаиії адсорбованих частинок або зміни заряду подвійного електричного шару при зміщенні потенціалу. При цььму виміряна ємність представляс собою вже не тільки ємність подвійного шару, яка відзеркалює зміни заряду електрода, але й перебіг на ньому електрохімічних реакиій. Виміряну в таких умовах ємність можна назвати поляризаиійною ємністю або просто псевдоємністю. 
Ключові слова: автотранспортний засіб, барабанно-колодкове гальмо, гальмівний барабан, фрикційна накладка, темп нагрівання та вимушеного охолодження, подвійні електричні шари, термостабілізаційний стан

Вступ. У першій частині було розглянуто:

- оцінку енергонавантаженості ободу гальмівного барабану автотранспортного засобу в різних умовах: лабораторних, експлуатаційних;

- природу виникнення і формування подвійних електричних шарів (ПЕШ) на міжфазній границі пар тертя гальмівних пристроїв.

У другій частині статті необхідно приділити увагу електричній складовій термостабілізаційного стану ободу гальмівного барабану гальма автотранспортного засобу.

Стан проблеми. Існування подвійного електричного шару на міжфазній границі двох середовищ (робоча поверхня гальмівного барабана - робоча поверхня полімерного фрикційного елемента), а також на гарячій і холодній поверхнях приповерхневого шару фрикційної накладки вносить хаос не тільки в іонічний обмін між поверхнями тертя, але й у процеси адсорбції [1] та дифузії [2] іонів та електронів у приповерхневих шарах пар тертя. Наявність (ПЕШ) сприяє електроповерхневим процесам, які є складовими електрокінетичних явищ, що мають місце у приповерхневих шарах фрикційних накладок.

Відомо, що основні дані про будову (ПЕШ) отримано з ємнісних вимірювань за відсутності переносу зарядів крізь міжфазну границю. У реальних умовах робота наноелектроніки процес ускладнюється: стає можливим перенесення зарядів за рахунок електрохімічної реакції, іонізації адсорбованих частинок або зміни заряду (ПЕШ) при зміщенні потенціалу. А чого варте виникнення стрибка потенціалу на границі «метал - електроліт» за рахунок окислення і відновлення самого металу, яким є робоча поверхня металевого елемента, що фрикційно взаємодіє поверхнею полімерної накладки.

Постановка задачі. В даній публікації розглянуті наступні питання стосовно вирішувальної проблеми:

- енергетична оцінка подвійних електричних шарів у парах тертя гальм;

- термостабілізаційний стан металевого фрикційного елемента гальм.

Мета роботи - обгрунтувати, що при температурах вище допустимої для матеріалів поверхневих та приповерхневих шарів фрикційної накладки в зоні тертя виникає множина подвійних електричних шарів 3 різною енергетичною активністю, які сприяють інверсії теплових потоків від полімеру до металу і виникненню стійкої теплової стабілізації при мінімальному температурному градієнті товщини металевого фрикційного елемента.

Енергетична оцінка подвійних електричних шарів в парах тертя гальм. Подвійні електричні шари в парах тертя відіграють важливу роль у підсиленні трибоефекту в парах тертя гальмівних пристроїв.

Оскільки товщина $d$ (ПЕШ) є величиною малою (порядку декількох міжатомних відстаней), спостерігається висока ємність на одиницю поверхні (20-50

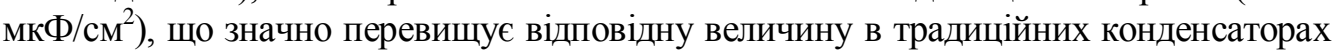
(діелектрик має товщину 5-7 сотень міжатомних відстаней).

Для оцінки товщини (ПЕШ) між робочою поверхнею фрикційних накладок (не взаємодіють з полірованою поверхнею ободу барабана автотранспортного 
засобу) і нижнім рівнем приповерхневого шару накладок розглянемо модель побудови подвійного електричного шару на границі розділу метал / розчин електроліту (рис. 1). Коли на границі фаз діють тільки електричні сили, іони в розчині можуть підійти до поверхні металу на відстань не ближче, ніж радіус сольватного іона, оскільки на поверхні металу зберігається мономолекулярний шар адсорбованого розчинника. Площину, проведену через центри найближчих поверхонь іонів, називають зовнішньої площиною Геймгольца (площина $X_{1}$ на рис. $1, a$ ). У разі специфічної адсорбції іонів, коли вони повністю або частково втрачають сольватну оболонку, центри адсорбованих іонів можуть підійти до поверхні на більш близьку відстань, а площину, проведену через їх центри, називають внутрішню площиною Геймгольца (площина $X_{2}$ на рис. $1, a$ ).

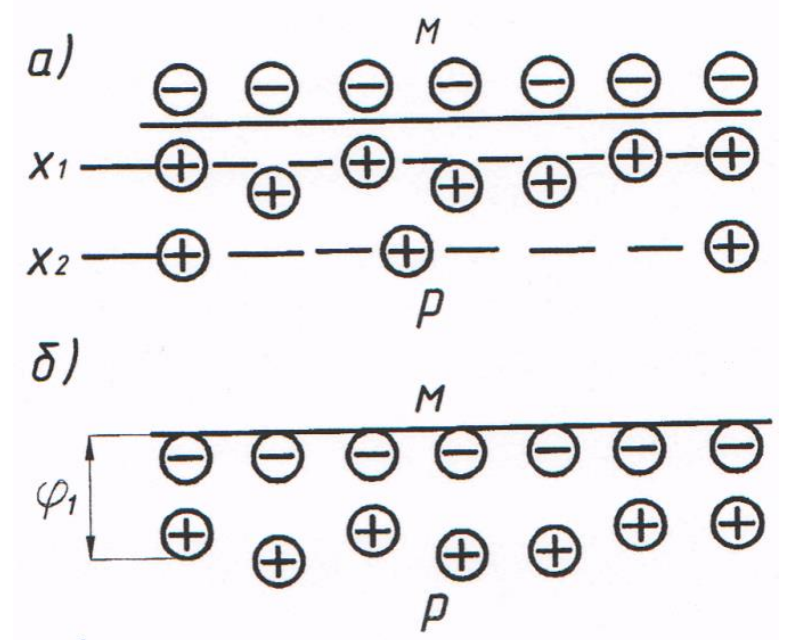

B)

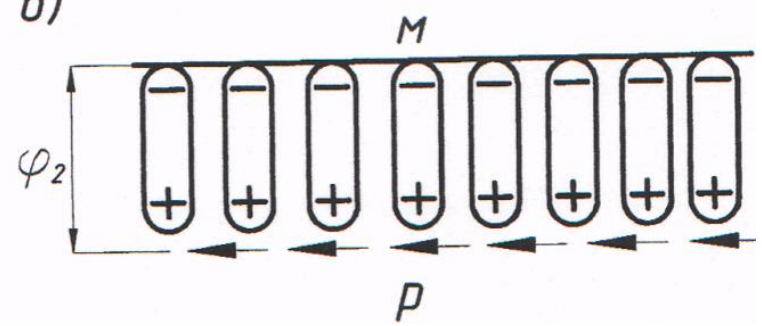

Рис. 1. Схеми будови зовнішнього $(a)$ і внутрішнього $(\sigma, 6)$ подвійного електричного шару у приповерхневих зонах пар тертя: $M$ - метал; $P$ - розчин електроліту; $\leftarrow \leftarrow-$ площина ковзання

В об'ємі розчину електроліту за зовнішньою площиною Геймгольца розташовується дифузійний іонний шар, а потенціал $\varphi_{1}$ (рис. $\left.1, \sigma\right)$ називають потенціалом дифузійного шару. Незважаючи на те, що площина заряду в дифузійному шарі знижується в міру віддалення від поверхні фрикційних накладок, ії можна уподібнити до циліндричного конденсатора 3 деякою ефективною відстанню між обичайками, іншими словами, охарактеризувати ефективною товщиною дифузійного шару Л.

Теоретично Л описується залежністю вигляду [2]:

$$
\Pi=\sqrt{\frac{\varepsilon_{r} R T}{8 \pi c F^{2}}},
$$


де $\varepsilon_{r}$ - відносна діелектрична проникність розчину електроліту; $R$ - універсальна газова стала; $T$ - абсолютна температура; $c$ - іонна концентрація; $F$ - число Фарадея.

Із залежності (1) видно, що при зниженні концентрації іонів товщина дифузійного шару збільшується, тобто границя зарядженого шару зміщується вглиб електроліту поверхневого шару накладки. У сильно розведених розчинах електроліту границя дифузійного шару може зміщуватися за границю так званого шару ковзання, тобто площини, за границями якої стає можливим рух рідини уздовж міжфазової границі. Отже, при протіканні рідини уздовж границі «тверде тіло / рідина» відбувається переміщення об'ємного заряду i, відповідно, 3'являється різниця потенціалів вздовж потоку рідини. Явище, яке пов'язано 3 появою об'ємного заряду в розчині електроліту за межами площини ковзання називається електрокінетичним. Потенціал площини ковзання називають електрокінетичним потенціалом $\varphi_{2}$ (рис. 1,8$)$.

Важливо відзначити, що основні дані про будову (ПЕШ) отримано з ємнісних вимірювань за відсутності переносу зарядів крізь міжфазну границю. У реальних умовах роботи пристроїв молекулярної електроніки процес ускладнюється: стає можливим перенесення зарядів за рахунок електрохімічної реакції, іонізації адсорбованих частинок або зміни заряду (ПЕШ) при зміщенні потенціалу. При цьому виміряна ємність представляє собою вже не тільки ємність подвійного шару, яка відзеркалює зміни заряду електрода, але й перебіг на ньому електрохімічних реакцій. Виміряну в таких умовах ємність можна назвати поляризаційною ємністю або просто псевдо ємністю [3, 4].

Існування подвійного електричного шару на міжфазній границі двох середовищ (робоча поверхня гальмівного барабана - робоча поверхня полімерного фрикційного елемента), а також на гарячій і холодній поверхнях приповерхневого шару фрикційної накладки грає важливу роль не тільки в іонному обміні між поверхнями тертя, але й у процесах адсорбції іонів поверхонь пар тертя гальм. Наявність подвійного електричного шару істотно впливає на електроповерхневі процеси: провідності, поляризації дисперсних частинок, масо- і енергопереміщення крізь заряджені дисперсні системи, електростатичної взаємодії між зарядженими частинками і таке ін. При цьому електроповерхневі процеси є складовими електрокінетичних явищ, що мають місце у приповерхневих шарах фрикційних накладок [5].

Механізм виникнення стрибка потенціалу на границі «метал - електроліт» за рахунок окислення і відновлення самого метала, яким $є$ робоча поверхня металевого фрикційного елемента, що знаходиться на поверхні полімерної накладки (рис. 2) може бути представлено наступним чином. Катіони, які знаходяться на робочій поверхні металевого фрикційного елемента, мають в середньому запас потенціальної енергії, що відповідає точці 1 на рис. 2. Переміщення катіона в енергетичному полі вліво, тобто втиснення його в метал робочої поверхні тертя або зближення з сусідніми катіонами його кристалічної решітки, потребує більшої роботи на подолання сил відштовхування, що виражається висхідною енергетичною кривою $1-1$. Переміщення катіона вправо, тобто відрив його від робочої поверхні металевого фрикційного елемента при електротермомеханічному терті з переходом у вакуум, потребує настільки більшої роботи (крива $1-1$ ), що відповідає енергії випаровування $U_{u}$, оскільки при поверхневій температурі нижче допустимої для матеріалів полімерної накладки цей процес практично не має місця. 


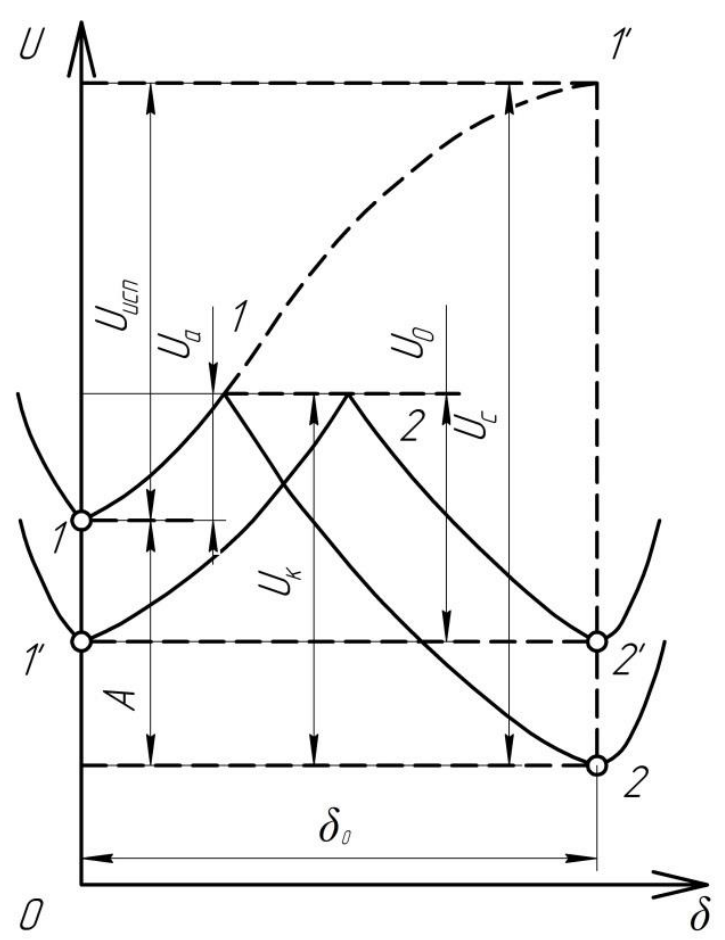

Рис. 2. Схема зміни енергії при випаровуванні катіонів при поверхневого шару накладки при електротермічній фрикційній взаємодії пар тертя: 1, 2 - моменти: контактування металу з розчином та встановлення рівноваги в трибоспряженні

Полярні молекули електроліта - сольвента (наприклад, води), відповідно орієнтуючись біля поверхневих катіонів метала (див. рис. 2) полегшують перехід катіонів в електроліт з вивільненням енергії сольватації так як рівень соль ватованого іона нижче, ніж катіона метала у вакуумі, на величину $U_{c}$, так що енергія катіонів, що знаходяться в електроліті на найближчій можливій відстані $\delta_{0}$ від робочої поверхні металевого фрикційного елемента, відповідає точці 2 на рис. 2.

Висхідні вліво і вправо енергетичні криві соль ватованого іона відповідають, відповідно, відриву катіона від сольватуючих його молекул електроліту і зближенню катіона з молекулами електроліту на відстані, менші, ніж у мимовільно утвореному соль ватному комплексі.

Для переходу в електроліт поверхневий катіон метала повинен подолати лишень енергетичний бар'єр (рис. 2, крива $l^{\prime}-2$ ), причому $U_{a}<<U_{c}$, тобто цей процес $\epsilon$ більш ймовірним. Різниця рівнів потенціальних енергій в точках 1 i 2 , що дорівнює А, відповідає роботі процесу переходу 1-го іона металу в електроліт. Для переходу з електроліту в метал, що знаходиться в електроліті сольватований катіон повинен подолати енергетичний бар'єр $U_{\kappa}$ (рис. 2 крива $2-1$ ), причому $U_{k}>U_{a}$, тобто цей процес (катодний) є менш імовірним, ніж перший (анодний).

Таким чином, якщо при взаємодії металу з електролітом фазову границю перетинають тільки іони металу, то, за даними досліджень А. Н. Фрумкіна і його школи, протікають два спряжені процеси:

- перехід зазначених іонів з металу в електроліт з утворенням сольватованих іонів (окислювальний або анодний процес):

$$
\mathrm{Me}+\mathrm{mH}_{2} \mathrm{O}=\mathrm{Me}^{n}+\mathrm{mH}_{2} \mathrm{O}+n e,
$$


де $M e$ - метал; $m$ - число атомів металу в молекулі оксиду; $n e$ - кількість іонів та електронів, які виникають; при цьому швидкість цього процесу, яка вимірюється числом іонів, що переходять з фази у фазу через одиницю площі поверхні фрикційної взаємодії в одиницю часу, виражається через виникаючу густину струму $\vec{i}$;

- розряд цих іонів з електроліту з виділенням їх на поверхні металу у вигляді нейтральних атомів, що входять до складу кристалічної решітки металу (відновлювальний або катодний процес)

$$
\mathrm{Me}^{n}+\mathrm{mH}_{2} \mathrm{O}+n e=\mathrm{Me}+\mathrm{mH}_{2} \mathrm{O},
$$

швидкість якого також може бути виражена через відповідну густину струму $\bar{i}$.

Який із зазначених процесів переважає при електротермомеханічному терті, визначається рівнем потенціальної енергії катіонів у вузлах кристалічної решітки металу $U_{1}$ і в електроліті $U_{2}$. Якщо $U_{1}>U_{2}$, то $\vec{i}>\overleftarrow{i}$, тобто переважає анодний процес - перехід іонів металу в електроліт (див. рис. 2), сумарна швидкість якого дорівнює

$$
i_{a}=\vec{i}-\overleftarrow{i}
$$

якщо $U_{2}>U_{1}$ то $\bar{i}>\vec{i}$, тобто переважає катодний процес - розряд іонів металу 3 електроліту, сумарна швидкість якого дорівнює

$$
i_{k}=\overleftarrow{i}-\vec{i}
$$

При $U_{1}>U_{2}$ (рис. 2) перехід частини катіонів в електроліт супроводжується зниженням середньої потенціальної енергії поверхневих катіонів (точка 1 переміщується вниз), появою на металевій поверхні надлишкових негативних зарядів i підвищенням енергетичного бар'єра $U_{a}$. Підвищення концентрації іонів біля поверхні металу супроводжується зростанням запасу їх енергії (точка 2 переміщається вверх), набуттям електролітом надлишкового позитивного заряду і зниженням ене-

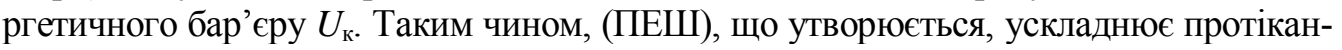
ня прямого процесу і полегшує протікання зворотного процесу.

Коли енергетичний рівень іонів на поверхні металу і в електроліті стає однаковим, тобто $U_{1}^{\prime}=U_{2}^{\prime}$ (що настає зазвичай досить швидко), встановлюється динамічна рівновага, при якій $U_{a}=U_{\text {к }}=U_{0}$ і швидкості анодного і катодного процесів рівні:

$$
\vec{i}=\overleftarrow{i}=i_{0},
$$

де $i_{0}$ - густина струму обміну, яка зумовлена постійно протікаючим обміном іонами між металом і електролітом [6].

Після досягнення рівноваги зміни маси металу $\Delta m=0$, тобто розчинення робочої поверхні металевого фрикційного елемента не відбувається.

Термостабілізаційний стан металевого фрикційного елемента. Дослідження термостабілізаційного стану здійснено до ободу заднього гальмівного барабану транспортного засобу ЗІЛ-130.

Згідно з рис. 3, а темпи нагрівання робочої і неробочої зони фрикційної накладки визначалися в інтервалі часу $0 . .720$ с за поліноміальною регресією вигляду:

$$
\begin{gathered}
\frac{\Delta T}{\Delta \tau}=3,522 \cdot 10^{-6} x^{2}-3,375 \cdot 10^{-3} x+0,827 \\
\frac{\Delta T}{\Delta \tau}=8,929 \cdot 10^{-6} x+0,125 .
\end{gathered}
$$




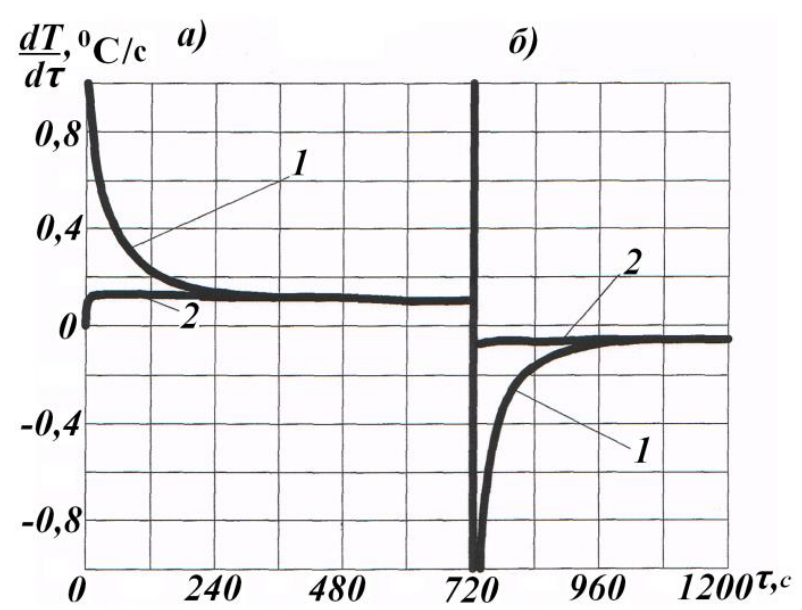

Рис. 3. Закономірності зміни темпів нагрівання $(a)$ і вимущеного охолодження (б) робочої (l) і неробочої (2) зон приповерхневого шару фрикційної накладки задньої гальмівної колодки автотранспортного засобу ЗІЛ-130 протягом випробувань типу II i після його завершення

Згідно з рис. 3, б темпи вимушеного охолодження робочої і неробочої зон накладки визначалися в інтервалі часу $0 . .480$ с за поліноміальною регресією вигляду:

$$
\begin{gathered}
\frac{\Delta T}{\Delta \tau}=-1,855 \cdot 10^{-5} x^{2}+0,012 x-1,804 ; \\
\frac{\Delta T}{\Delta \tau}=1,667 \cdot 10^{-5} x-0,046 .
\end{gathered}
$$

Різка зміна питомих часток теплоти робочої зони фрикційної накладки, яка витрачається на акумулювання теплоти ії̈ приповерхневим шаром спостерігається протягом 300 с випробувань, після чого темп нагрівання стабілізується і стає таким, як і нижнього рівня приповерхневого шару накладки. Пояснюється це тим, що у поверхневому шарі накладки починається взаємодія компонентів фрикційного матеріалу, яка має характер ендотермічних хімічних реакцій. Після 300 с нагрівання стає можливою інверсія струму електризації, спричинених іонізованою газовою сумішшю і десорбцією вологи з приповерхневих шарів накладки при додатному квазістабільному темпі їх нагрівання.

Темпи охолодження робочої зони приповерхневого шару і його нижнього рівня фрикційної накладки до 240 с після завершення випробувань стабілізуються при від'ємних значеннях.

Накладемо температурні поля ободу гальмівного барабана автотранспортного засобу та фрикційних накладок гальмівних колодок барабанно-колодкового гальма з метою оцінки їх загальної теплонавантаженості.

Аналіз графічної залежності, наведеної на рис. 4, $a$ показує, що температури пар тертя гальма залежать від інтенсивності зміни питомих навантажень у зоні контакту. При цьому температура приповерхневого шару завтовшки 200 мікрон досягає $120{ }^{\circ} \mathrm{C}$. У той же час у зоні температур $250 \ldots .270{ }^{\circ} \mathrm{C}$ робочої поверхні ободу барабана автотранспортного засобу спостерігається 12-ти секундний (короткотривалий) термостабілізаційний стан [7].

На рис. 4, б температурне поле зображено за допомогою чотирьох кривих, які відповідають закономірностям зміни температури по товщині ободу бараба- 
на автотранспортного засобу і фрикційної накладки в характерні моменти часу: 750 с - завершення попереднього етапу випробувань типу II; 723 с - початок основного етапу випробувань типу II (тривалий режим гальмування); 726 с завершення основного етапу випробувань типу II; 730 с - чотирисекундне вимушене охолодження (відповідає часу вимірювання поверхневої температури) після завершення випробувань типу II.

a)

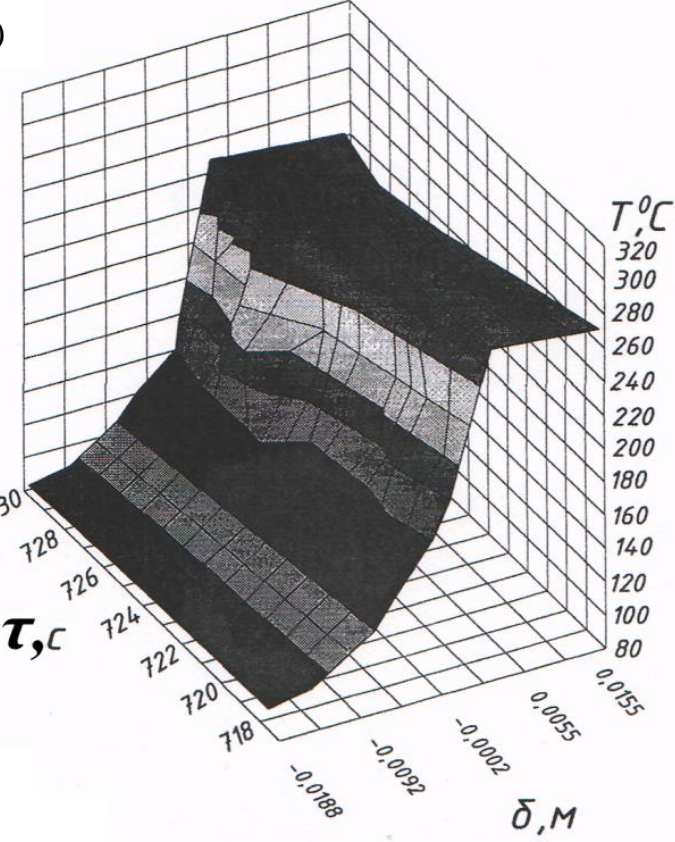

\begin{tabular}{|l|}
\hline $280-300$ \\
$280-300$ \\
$260-280$ \\
$240-260$ \\
$220-240$ \\
$200-220$ \\
$180-200$ \\
$160-180$ \\
$140-160$ \\
$120-140$ \\
$100-120$ \\
$80-100$ \\
\hline$\square$
\end{tabular}

б) $\div 0$

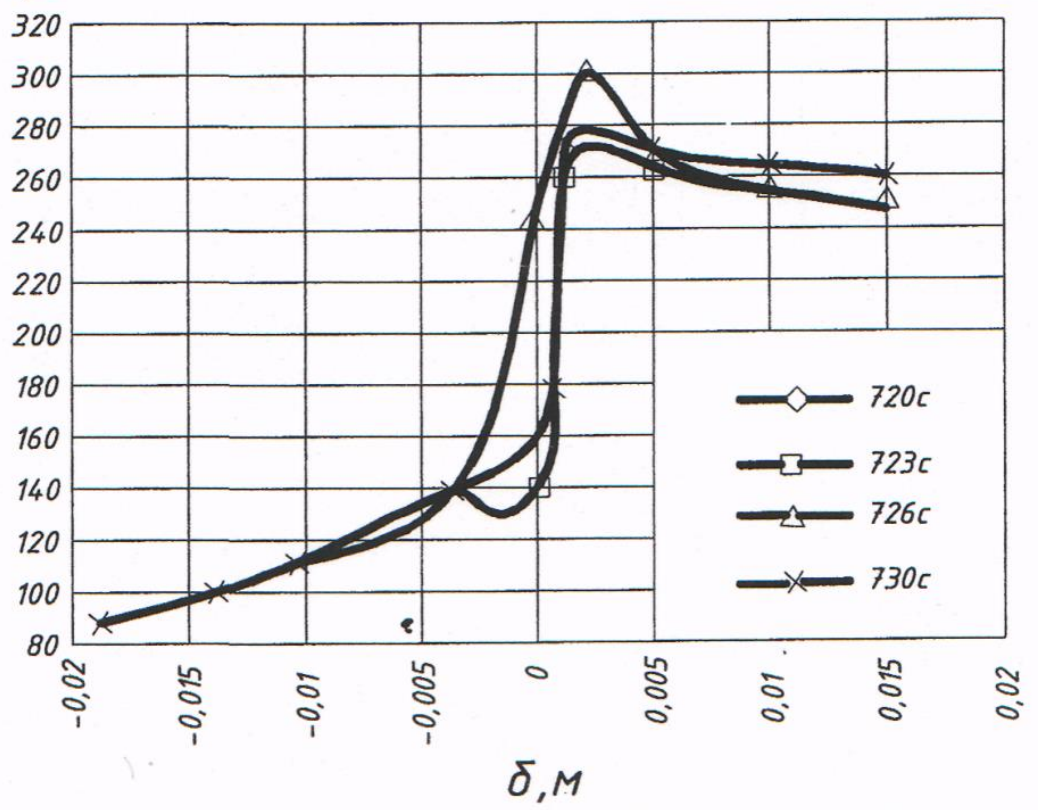

Рис. 4. Закономірності зміни по товщині ободу і фрикційної накладки в кінці попереднього етапу випробувань типу II у тривимірному ( $a$ ) і двовимірному (б) зображеннях 
Як видно з графічних залежностей, наведених на рис. 4, б, в кінці попереднього етапу випробувань типу II (довготривалого) перепад середніх температур між приконтактними зонами поверхонь тертя становить $100^{\circ} \mathrm{C}$. Після розмикання фрикційних вузлів гальма перед початком основного етапу випробувань перепад температур складає $120{ }^{\circ} \mathrm{C}$ через інтенсивні термодеструкційні процеси в приповерхневих шарах накладок (приповерхневих температурах вище допустимої для їх матеріалів). У кінці основного етапу випробувань типу II перепад температур різко знижується до $55^{\circ} \mathrm{C}$, що пояснюється збільшенням питомих навантажень на поверхнях взаємодії і нездатністю ними миттєво відвести значну кількість генерованої теплоти до сусідніх шарів тіла ободу, а особливо, відвести приповерхневими шарами накладок в їх товщину. Після завершення основного етапу випробувань типу II температурний перепад знову зростає до $110{ }^{\circ} \mathrm{C}$, що згідно з рис. 4, б (права частина) підтверджує короткотривалий термостабілізаційний стан ободу барабана автотранспортного засобу в інтервалі температур $250-270{ }^{\circ} \mathrm{C}$.

Достовірність даного методу, що забезпечує термостабілізаційний стан ободу гальмівного барабана автотранспортного засобу, випливає з:

- наявності в гальмівному барабані автотранспортного засобу полірованої і матової поверхонь і безпосередньо вплив теплового стану його фланця на термостабілізацію ободу;

- теплової взаємодії ободу барабана автотранспортного засобу з його фланцем;

- виконання ободом барабана автотранспортного засобу функцій джерела теплової енергії в процесах теплопередачі, а також його полірованої поверхні функцій каталізатора для омиваючих ії повітряних і газових потоків;

- досягнення неоднакового теплового стану робочими поверхнями фрикційних накладок;

- можливості термохімічної реакції сполучних компонентів у приповерхневих шарах фрикційних накладок;

- наявності у міжконтактному зазорі пар тертя в достатній кількості іонізованого газового середовища і десорбованої вологи;

- виникнення подвійних електричних шарів між: «полірованою поверхнею ободу барабана автотранспортного засобу та робочою поверхнею фрикційних накладок» i «робочою поверхнею фрикційних накладок (які не взаємодіють 3 ободом барабана автотранспортного засобу) і нижнім рівнем приповерхневого шару накладок»;

- настання стабілізаційного теплового стану ободу гальмівного барабана автотранспортного засобу при інверсії теплових потоків від його робочої поверхні у приповерхневі шари фрикційних накладок.

Знання моментів часу настання термостабілізаційного стану ободу гальмівного барабана автотранспортного засобу дозволить:

- істотно доповнити обсяг знань в області теплової динаміки фрикційних вузлів гальмівних пристроїв;

- уточнити тепловий баланс і розрахунок теплового стану при нагріванні і вимушеному охолодженні металевих елементів тертя;

- обгрунтувати вибір площі матових і полірованих поверхонь гальмівного барабана при граничній умові не перевищення допустимої температури матеріалом фрикційної накладки, підвищити ресурс найслабшої ланки фрикційного вузла, тобто накладки; 
- раціонально вибрати матеріал фрикційних накладок при застосуванні нових типів фрикційних вузлів.

Висновки. Таким чином, термостабілізаційний стан підтримується міжконтактним іонізованим газовим середовищем і продуктами десорбції вологи (3 приповерхневого шару накладки) між подвійними електричними шарами («полірована робоча поверхня ободу барабана - робоча поверхня накладок» $\mathrm{i}$ «робоча поверхня накладок (невзаємодіюча $з$ робочою поверхнею ободу барабана автотранспортного засобу) - нижній рівень приповерхневого шару накладок). Виникаючі струми насичення сприяють інверсії теплових потоків від полірованої робочої поверхні ободу барабана автотранспортного засобу в приповерхневі шари накладок, спричиняючи його термостабілізаційний стан.

\section{Список літератури}

1. Расчет, испытание и подбор фрикционных пар / А.В. Чичинадзе, Э.Д. Браун, А.Г. Гинзбург, 3.В. Игнатьев. М.: Наука, 1989. 267 с.

2. Тепло- и массообмен. Теплотехнический эксперимент: Справочник / Е. В. Аметисов, В. А. Григорьев, Е. Т. Емцев [и др.]: Под общ ред. В. А. Григорьева и В. М. Зорина. - М.: Энергоиздат, 1982. - 512 с.

3. Материалы в триботехнике нестационарных процессов / А. В. Чичинадзе, Р. М. Матвиевский, Э. Д. Браун [и др]. М.: Наука, 1986. 245 с.

4. Чичинадзе А. В., Белоусов В. Я., Богатчук И. М. Износостойкость фрикционных полимерных материалов. Львов: Высшая школа, 1989. 267 с.

5. Обеспечение износостойкости изделий. Метод оценки фрикционной теплостойкости материалов: ГОСТ 23.210-80. М.: Изд-во стандартов, 1980. 9 с.

6. Volchenko N. Features of the estimation of the intensity of heat exchange in selfventilated disk-shoe brakes of vehicles / N. Volchenko, A. Volchenko, D. Volchenko, P. Poliakov, V. Malyk, D. Zhuravlov, V. Vitvitskyi, P. Krasin: Eastern-European Journal of Enterprise Technologies ISSN 1729-3774 1/5 (97)2019. P.47-53.

7. Лыков А. В. Теплообмен: Справочник / А. В. Лыков - М.: Энергия, 1972. 560 с.

Стаття надійшла до редакціїі 18.09.2020.

Вольченко Дмитро Олександрович - докт. техн. наук, професор кафедри видобування нафти і газу Івано-Франківський національний технічний університет нафти і газу, вул. Карпатская, 15, м. Івано-Франківськ, Україна, 76019, тел..: +38 03427271 41, моб. 050-373-82-42, E-mail: vol21@ukr.net.

Кіндрачук Мирослав Васильович - докт. техн. наук, професор, завідувач кафедри машинознавства, Київський національний авіаційний університет, пр. Любомира Гузара 1, м. Київ, Україна, 03058, E-mail: nau12@ukr.net.

Скрипник Василь Степанович - докт. техн. наук, професор кафедри автомобільного транспорту Івано-Франківський національний технічний університет нафти і газа, вул. Карпатская, 15, м. Івано-Франківськ, Украина, 76000, тел..: +38 03427271 41, моб. 050-950-04-18, E-mail: www.divo99@ukr.net.

Вольченко Микола Олександрович - канд. техн. наук, доцент, завідувач кафедри матеріалознавства та автосервіса Кубанського національного технологічного університету.

Вудвуд Олександр Миколайович - канд. техн. наук, доцент кафедри підйонотранспортого та робототехнічного обладнання, Одеський національний політехнічний університет, Україна, 65044, м. Одеса, пр. Шевченка, 1. 
D. O. VOLCHENKO, M. V. KINDRACHUK, V. S. SKRYPNYK, M. O. VOLCHENKO,

O. M. VUDVUD

\section{THERMOSTABILIZATION STATE OF METAL FRICTION ELEMENTS OF BRAKING DEVICES (PART II)}

The materials of the article consider the thermal stabilization state of the drum rim, which is supported by the contact ionized gaseous medium and moisture desorption products (from the surface layer of the lining) between the double electric layers (polished working surface of the drum the surface of the rim of the drum of the vehicle) - the lower level of the near-surface layer of the overlays). The resulting saturation currents contribute to the inversion of heat fluxes from the polished working surface of the rim of the drum of the vehicle in the near-surface layers of the pads, contributing to its thermal stabilization state. In highly diluted electrolyte solutions, the boundary of the diffusion layer can be displaced beyond the boundary of the so-called slip layer, ie the plane beyond which the movement of the liquid along the interfacial boundary becomes possible. Thus, as the fluid flows along the solid / liquid boundary, the bulk charge moves and, accordingly, a potential difference appears along the fluid flow. The phenomenon associated with the appearance of a bulk charge in the electrolyte solution outside the sliding plane is called electrokinetic. The sliding plane potential is called the electrokinetic potential. Double electric layers in friction pairs play an important role in amplifying the tribo effect in friction pairs of brake devices. The existence of a double electric layer on the interfacial boundary of two media (working surface of the brake drum - the working surface of the polymer friction element), as well as on hot and cold surfaces of the nearsurface friction lining plays an important role not only in ion exchange between friction surfaces. and in the processes of adsorption of ions of the surfaces of brake friction pairs. The presence of a double electric layer significantly affects the electrosurface processes: conductivity, polarization of dispersed particles, mass and energy displacement through charged dispersed systems, electrostatic interaction between charged particles, and so on. In this case, electrosurface processes are components of electrokinetic phenomena that occur in the near-surface layers of friction pads. It is important to note that the basic data on the structure of the electric double layer are obtained from capacitive measurements in the absence of charge transfer through the interfacial boundary. In real operating conditions of molecular electronics devices, the process is complicated: it becomes possible to transfer charges due to electrochemical reaction, ionization of adsorbed particles or change the charge of the electric double layer when the potential is shifted. In this case, the measured capacitance represents not only the capacitance of the double layer, which reflects changes in the charge of the electrode, but also the course of electrochemical reactions on it. The capacitance measured in such conditions can be called polarization capacitance or simply pseudocapacitance.

Key words: motor vehicle, drum-pad brake, brake drum, friction pad, heating and forced cooling rate, double electric layers, thermal stabilization state

\section{References}

1. Raschet, ispytaniye i podbor friktsionnykh par / A.V. Chichinadze, E.D. Braun, A.G. Ginzburg, Z.V. Ignat'yev. M.: Nauka, 1989. 267 s.

2. Teplo- i massoobmen. Teplotekhnicheskiy eksperiment: Spravochnik / Ye. V. Ametisov, V. A. Grigor'yev, Ye. T. Yemtsev [i dr.]: Pod obshch red. V. A. Grigor'yeva i V. M. Zorina. - M.: Energoizdat, 1982. - 512 s.

3. Materialy v tribotekhnike nestatsionarnykh protsessov / A. V. Chichinadze, R. M. Matviyevskiy, E. D. Braun [i dr]. M.: Nauka, 1986. 245 s.

4. Chichinadze A. V., Belousov V. Ya., Bogatchuk I. M. Iznosostoykost' friktsionnykh polimernykh materialov. L'vov: Vysshaya shkola, 1989. $267 \mathrm{~s}$.

5. Obespecheniye iznosostoykosti izdeliy. Metod otsenki friktsionnoy teplostoykosti materialov: GOST 23.210-80. M.: Izd-vo standartov, 1980. 9 s.

6. Volchenko N. Features of the estimation of the intensity of heat exchange in selfventilated disk-shoe brakes of vehicles / N. Volchenko, A. Volchenko, D. Volchenko, P. Poliakov, V. Malyk, D. Zhuravlov, V. Vitvitskyi, P. Krasin: Eastern-European Journal of Enterprise Technologies ISSN 1729-3774 1/5 (97)2019. P.47-53.

7. Lykov A. V. Teploobmen: Spravochnik / A. V. Lykov - M.: Energiya, 1972. 560 s. 